\title{
Studies on the Adsorption of $\mathrm{Pb}$ (II) and Zn (II) as Binary Mixtures from Industrial Effluents
}

\author{
Jagjit Kour ${ }^{*}$, Bindra Shrestha ${ }^{1}$ and Kedar Nath Ghimire ${ }^{2}$ \\ ${ }^{1}$ Department of Chemistry, Tri-Chandra College, Tribhuvan University, Nepal. \\ ${ }^{2}$ Central Department of Chemistry, Tribhuvan University, Kathmandu, Nepal. \\ *Corresponding Author Email: jagjit_kour@hotmail.com \\ Received 10 October 2017, Revised 09April 2018, Accepted 16 April 2018
}

\begin{abstract}
The present work focuses on the adsorptive removal of mixtures of heavy-metal ions present in industrial effluents, using modified bio-sorbent prepared from Desmostachya bipinnata (MDB). The prepared biosorbent was characterized by SEM, DRFTIR, Elemental analyzer, XRD, Boem titration and point of zero charge, showing modificatios on the surface of the biosorbent. The adsorption behavior of two different metals, $\mathrm{Pb}$ (II) and $\mathrm{Zn}$ (II), indicated regular patterns of adsorption. Their adsorption behavior as binary mixtures was evaluated, which showed the interference of one metal ions with another, thereby reducing the adsorption capacities of both metal ions. Even though there is interference between two different metal ions, the modified biosorbent proved quite efficient in removing complex mixtures of heavy metal ions from industrial effulents.
\end{abstract}

Keywords: Binary mixture, Modified biosorbent, Industrial effluents, Metal ions, Adsorption.

\section{Introduction}

Industrial effluents containing different types of toxic heavy metal ions are major sources of water pollution. It has always been a challenge to remove different heavy metal ions from contaminated water. Large numbers of experiments have been performed with various plant-based biomasses, particularly those that are cellulosic in nature, as potential biosorbents for the removal of single heavy metals ions $[1,2]$.

For economic reasons, low-cost biosorbents such as agricultural wastes have been attracting interest recently [3, 4]. But research focused on the adsorption of binary or complex mixtures of heavy metal ions from contaminated water has remained marginal $[5,6]$. Contaminated water from industries contains different types of heavy metals, rather than just a single metal ion.

It is therefore necessary to study the competitive adsorption and the interference of metal ions in the effluents from industries [7, 8]. In this study $\mathrm{Pb}$ (II) and $\mathrm{Zn}$ (II) are taken as binary mixture. Among these metals, $\mathrm{Pb}$ (II) is a toxic heavy metal even at trace amount. Its compounds are used in paints and ceramics. One of the major sources of environmental pollution by $\mathrm{Pb}$ (II) is the exhaust gases generated from vehicles which contains oxides, halides and alkyl compounds of lead.

$\mathrm{Zn}$ (II) is an essential element for human beings since it is a cofactor of many enzymes, but its excess intake is harmful for living organisms. Its oxide is used as a white pigment in paints. It is also used in plastics, cosmetics, photocopy paper, wall paper and printing inks.

The individual study on $\mathrm{Pb}$ (II) and $\mathrm{Zn}$ (II) showed regular patterns of adsorption capacities, where $\mathrm{Pb}$ (II) has high adsorption capacity as compared to $\mathrm{Zn}$ (II). 
Due to large difference in their adsorption capacities, the interference between two ions will not be very complicated, and it will be easy to study the adsorption behavior of the binary mixture of $\mathrm{Pb}$ (II) and $\mathrm{Zn}$ (II).

For the adsorption of $\mathrm{Pb}$ (II) and $\mathrm{Zn}$ (II), Desmostachya bipinnata is used as a biosorbent. It contains cellulose, hemicelluloses and lignin as major constituents, as shown in Table1. The lignocellulosic material is rich in amount of easily accessible hydroxyl groups and other variety of functional groups, which may be involved in the attachment of amino groups on the surface of the biosorbents, thus making it suitable for metal adsorption [9].

Table 1. Major constituents in the Biosorbent D. bipinnata.

\begin{tabular}{lccc}
\hline Biosorbent & Cellulose \% & Hemicellulose \% & Lignin \% \\
\hline RDB & 27.36 & 35.04 & 7.64 \\
MDB & 5.83 & 3.86 & 71.05
\end{tabular}

The sorption mechanisms of lignocellulosic materials differ from those of other conventional adsorbents. These mechanisms are complicated because they implicate the presence of different interactions. Metal complexation by $N$ functionalized biosorbents may involve two different mechanisms: chelation and ion exchange, depending on the $\mathrm{pH}[10,11]$. The modified biosorbent prepared from $D$. bipinnata possesses high percentage of nitrogen atoms, present in the form of amine groups that are responsible for metal-ion binding through complexation. Amine sites are the main reactive groups for metal ions, which contribute to adsorption of metal ions [12].

This study is focused on the adsorption behavior and effects of interference of $\mathrm{Pb}$ (II) metal ions upon the adsorption of $\mathrm{Zn}$ (II) metal ions, in a binary mixture.

\section{Materials and Methods Chemicals}

All the reagents and chemicals used in this study were supplied by Fisher scientific analytical grade. Standard stock solutions (1000 mg/L) of $\mathrm{Pb}$ (II), and $\mathrm{Zn}$ (II) were prepared in Millipore, milli-
$\mathrm{Q}$ deionised water from their nitrate and sulphate salts, respectively. All the working solutions of various concentrations were diluted as required. 0.1M HEPES (2-[4-(2-Hydroxymethyl)-1-piperazinyl] ethanesulphonic acid), was used as the buffering agent $[13,14]$. The $\mathrm{pH}$ of the working solution was adjusted with dilute nitric acid and sodium hydroxide solutions.

All batch experiments were performed by taking $25 \mathrm{mg}$ of biosorbent along with $20 \mathrm{~mL}$ of metal ion solution in a $50 \mathrm{~mL}$ Erlenmeyer flask, and shaken for $24 \mathrm{~h}$ to maintain equilibrium at 150 $\mathrm{rpm}$ at lab temperature $\left(25^{\circ} \mathrm{C}\right)$. After $24 \mathrm{~h}$, the solutions were filtered through cellulose-free filter paper and the equilibrium concentrations of metal ions were measured with ICP-AES (inductively coupled plasma atomic emission spectrophotometer). (SPECTRO, Analytical Instrument, Kleve and Germany).

Various types of functional groups present in D. bipinnata were analyzed with diffuse reflectance fourier transform infrared spectroscopy (DRFTIR, Harrick scientific corporation). Elemental analysis was done with Elementary Vario Macro elemental analyzer.

\section{Biosorbent preparation}

Raw Desmostachya bipinnata (RDB) powder was treated with acid, followed by modification with dimethylamine, resulting in modified Desmostachya bipinnata (MDB). The method of preparing this biosorbent is published in earlier papers $[15,16]$.

\section{Batch adsorption studies for single metal ions Studies on effects of $\mathrm{pH}$}

The effect of $\mathrm{pH}$ on removal of $\mathrm{Pb}$ (II) and $\mathrm{Zn}$ (II) were studied at $50 \mathrm{mg} / \mathrm{L}$ of metal ions concentration as the function of $\mathrm{pH}(\mathrm{pH}=1-7)$, using batch method .

The amount of metal ions adsorbed was calculated from the decrease in metal ion concentration from which percentage adsorption (A \%) was calculated [17] as shown in equation (1). 
$\mathrm{A} \%=\frac{\mathrm{C}_{\mathrm{i}}-\mathrm{C}_{\mathrm{e}}}{\mathrm{C}_{\mathrm{i}}} \times 100$

where $\mathrm{C}_{\mathrm{i}}$ and $\mathrm{C}_{\mathrm{e}}$ represent initial and equilibrium concentrations of metal ion $(\mathrm{mg} / \mathrm{L})$ in the aqueous solution.

\section{Studies on point of zero charge}

The $\mathrm{pH}_{\mathrm{pzc}}$ measurements were carried out at different $\mathrm{pH}$ from 1-12. A volume of $20 \mathrm{~mL}$ of distilled water was taken in separate flasks and $\mathrm{pH}$ was adjusted with the $0.1 \mathrm{M}$ nitric acid and sodium hydroxide, respectively.

RDB and MDB (25 mg) were added to each flask separately, shaken at $150 \mathrm{rpm}$ and equilibrated for $2 \mathrm{~h}$. The mixtures were then filtered, optimum $\mathrm{pH}$ as well as the zeta potential of the solutions being measured using $\mathrm{pH}$ meter (Hanna instrument).

\section{Studies on metal uptake capacities}

The metal uptake capacities of MDB for $\mathrm{Pb}$ (II), and $\mathrm{Zn}$ (II) were separately evaluated by batch experiments with metal ion solutions at different concentrations from 25-500 $\mathrm{mg} / \mathrm{L}$ respectively, at their optimum $\mathrm{pH}$.

Initial and equilibrium concentrations of the respective metal ions were measured. The sorption capacity of metal ions (q in $\mathrm{mg} / \mathrm{g}$ ) is the concentration of metal ions on the biosorbent, which can be calculated from the mass balance principle as shown in equation (2).

$$
q=\frac{C_{i}-C_{e}}{W} \times V
$$

Where, $\mathrm{W}$ and $\mathrm{V}$ represent weight of the sorbent $(\mathrm{g})$ and volume of solution (L).

\section{Titrimetric method}

To evaluate the amount of acidic and basic functional sites present on the surface of the RDB and MDB, Boehm Titration was carried out. This method involves neutralization of surface acidic sites with base $(\mathrm{NaOH})$, and surface basic sites with acid $(\mathrm{HCl})$. The amount of functional groups present in the biosorbent is calculated in meq per gram according to the Boehm procedure [18].

\section{Elemental analysis}

The percentage amount of Carbon (C), Nitrogen $(\mathrm{N})$, and Sulphur (S) in RDB and MDB were measured using Elementary Vario Macro elemental analyzer.

\section{Scanning electron microscope (SEM) analysis}

The SEM (Hitachi S- 3000N scanning electron microscope) images of the RDB and MDB biosorbents were taken at low and high magnifications.

\section{Results and Discussion \\ Elemental analysis}

The biosorbent contains cellulose, hemicelluloses and lignin as major constituents, as shown in (Table 1). These constituents are also responsible for the adsorption of metal ions from aqueous solution.

The increase in percentage of nitrogen after modification was observed thereby supporting that nitrogen functional groups were grafted on D. bipinnataas shown in (Table 2).Therefore the adsorption capacity of modified biosorbent was found to be more than the raw biosorbent.

Table 2. Elemental analysis of $D$. bipinnata before and after modification.

\begin{tabular}{lccc}
\hline Biosorbent & Nitrogen \% & Carbon \% & Sulphur \% \\
\hline RDB & 1.13 & 41.27 & 0.56 \\
MDB & 5.42 & 52.12 & 2.31 \\
\hline
\end{tabular}

\section{Titrimetric method}

The Boehm titration of RDB showed $1.9 \mathrm{~m}$ $\mathrm{eq} / \mathrm{g}$ as acidic functional sites and $1.1 \mathrm{~m}$ eq/g basic functional sites which were changed to $1.3 \mathrm{~m} \mathrm{eq} / \mathrm{g}$ acidic and $3.5 \mathrm{~m} \mathrm{eq} / \mathrm{g}$ basic functional sites respectively. The increase in the value of basic functional sites after modification also suggests 
introduction of nitrogen functional groups on MDB.

\section{Scanning electron microscope (SEM) analysis}

The SEM images of the biosorbents before modification revealed smooth and even surface, as shown in Fig. 1 for RDB at low and high magnifications.

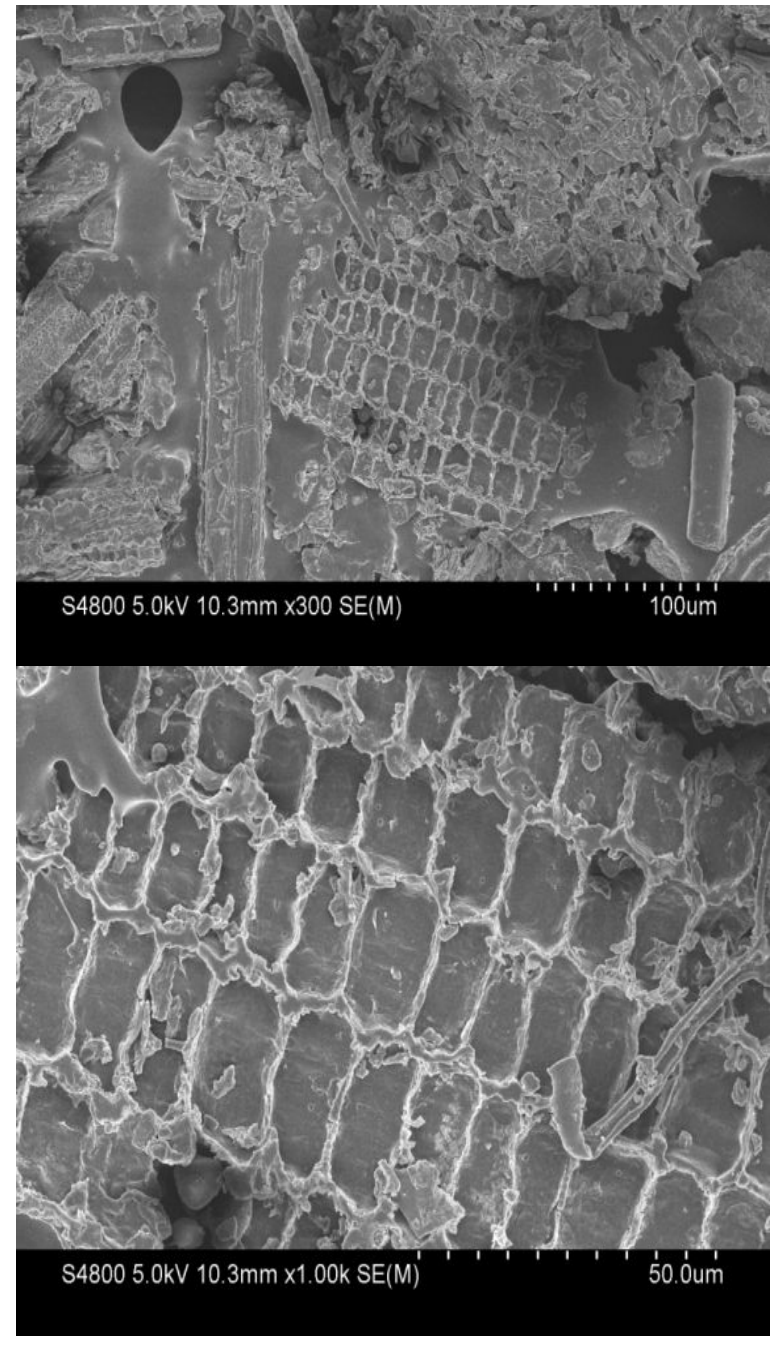

Figure 1. SEM of Raw $D$. bipinnata (RDB) with low \& high magnification

After modification of the biosorbents, surface morphology became porous, rough and corroded, as shown in Fig. 2, for MDB. This indicates change in surface morphology which may be due to incorporation of dimethylamine.

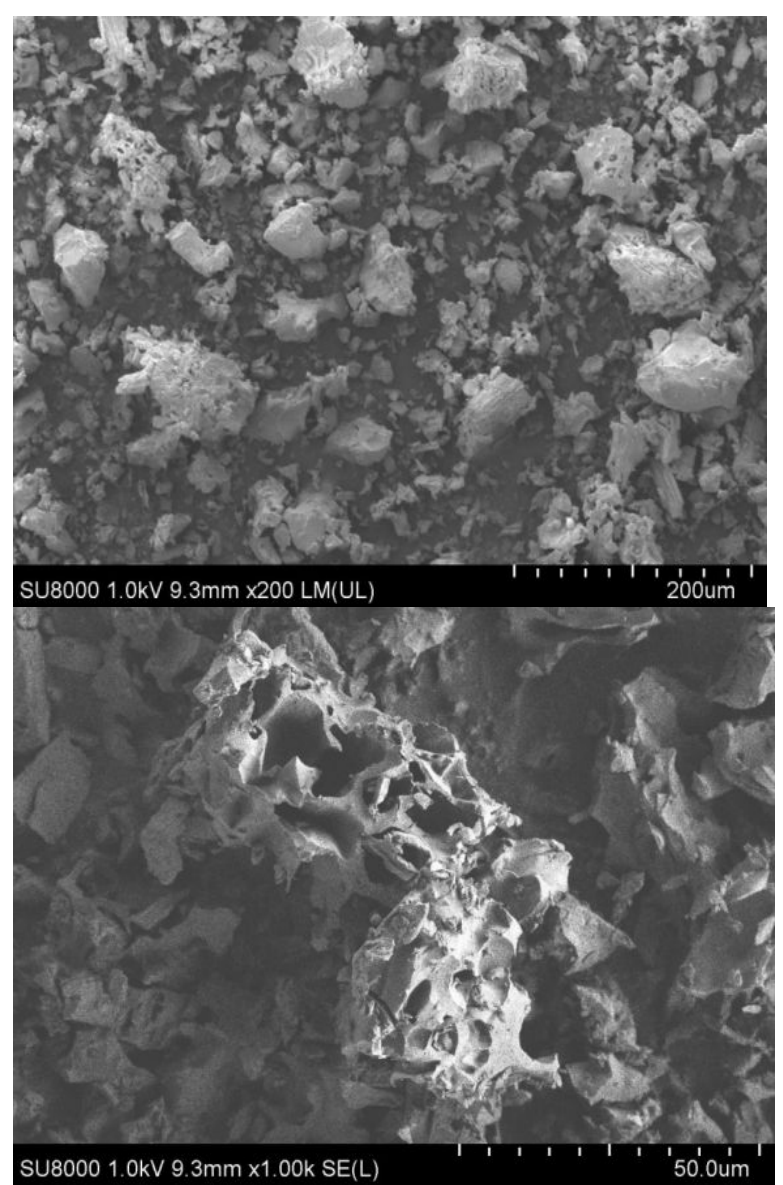

Figure 2. SEM of MDB with low \& high magnification

\section{Diffuse reflectance fourier transform infrared spectroscopy (DRFTIR) analysis}

The intense sharp adsorption peak around $3411 \mathrm{~cm}^{-1}$ (Fig. 3) for RDB corresponds to $\mathrm{O}-\mathrm{H}$ stretching vibration, due to hydrogen bonding of alcohols, phenols, and carboxylic acids as in cellulose, hemicelluloses and lignin, indicating the presence of free hydroxyl groups on the surface of the biosorbent.

The peak around $2926 \mathrm{~cm}^{-1}$ can be assigned to $\mathrm{C}-\mathrm{H}$ stretching in $\mathrm{CH}_{2}$ and $\mathrm{CH}_{3}$ groups. Similarly, the peak around $1736 \mathrm{~cm}^{-1}$ corresponds to carbonyl $C=O$ stretching vibration as well as stretching vibration of bond due to non ionic carboxylic groups like $-\mathrm{COOH}$ and $\mathrm{COOCH}_{3}[19,20]$. A major change in DRFTIR spectra was observed after the modification of biosorbent as shown in Fig. 3. The intense sharp peak at around $3411 \mathrm{~cm}^{-1}$ in RDB has been shifted 
to around $3480 \mathrm{~cm}^{-1}$ asabroad peak in MDB, which may be due to the merging of hydroxyl groups with amine groups. This also suggests grafting of amine functional groups on to the surface of biosorbent.

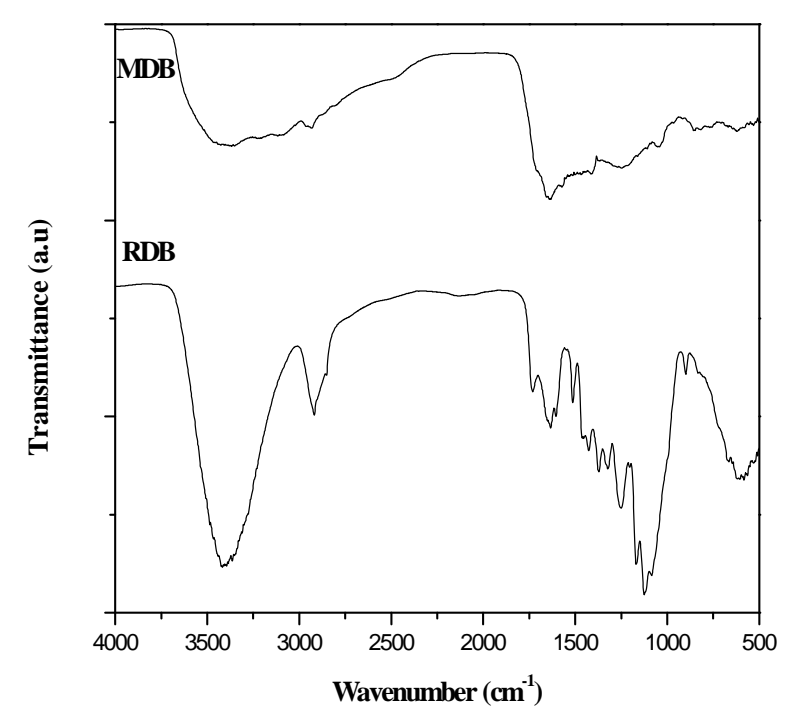

Figure 3. DRFTIR spectra of RDB and MDB

\section{X-Ray diffraction (XRD) analysis}

X-ray diffraction spectra of RDB and MDB are shown in Fig. 4(a) and 4(b). The reflection appears at $2 \theta=22^{\circ}$, with less intense peak in MDB as compared to RDB. This indicates reduced crystalline nature of MDB resulting in an improvement in metal ions sorption property [21].

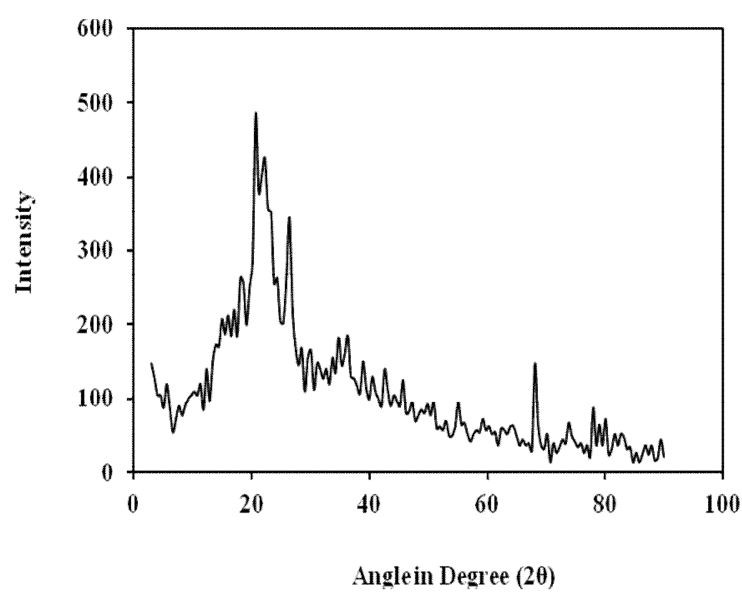

Figure 4(a). XRD spectrum of RDB

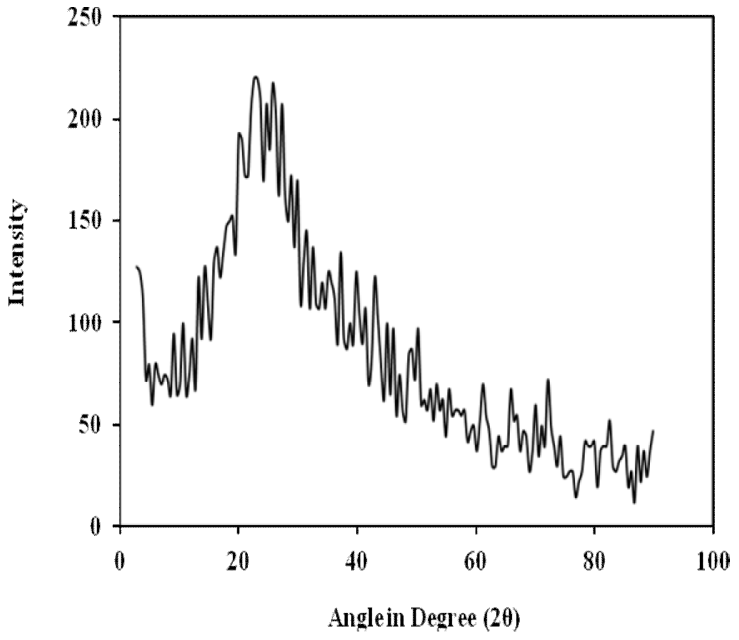

Figure 4(b). XRD spectrum of MDB

\section{Studies on effect of $\mathrm{pH}$}

The maximum sorption of $\mathrm{Pb}$ (II) and $\mathrm{Zn}$ (II) in their single solutions was found to be at their optimum $\mathrm{pH}$ values of 4 and 6 , respectively. Variation in $\mathrm{pH}$ could change the characteristics as well as the availability of metal ions in the solution. At low pH solution, large quantities of proton $(\mathrm{H}+)$ compete with the metal ion for binding on the functional groups onto the biosorbent surface. Hence, there would be a decrease in sorption of metal ions. As the $\mathrm{pH}$ increases, sorption of metal ions also increases, due to the decrease in competition between proton $\left(\mathrm{H}^{+}\right)$and metal species for the active sites on sorbent surface.

\section{Studies on point of zero charge}

The $\mathrm{pH}_{\mathrm{pzc}}$ is the $\mathrm{pH}$ at which the net charge of the surface of biosorbent becomes zero [22]. The surface of the biosorbent is positive below 6 $\mathrm{pH}$ and negative above $6 \mathrm{pH}$.

The $\mathrm{pH}_{\mathrm{pzc}}$ value shifts towards higher $\mathrm{pH}$ ranges around 10 after modifications of the biosorbent, as shown in Fig. 5. This suggests modifications with nitrogen functional groups on the surface of biosorbent. These nitrogen functional groups are protonated, resulting in the positive charge on biosorbent surface. 


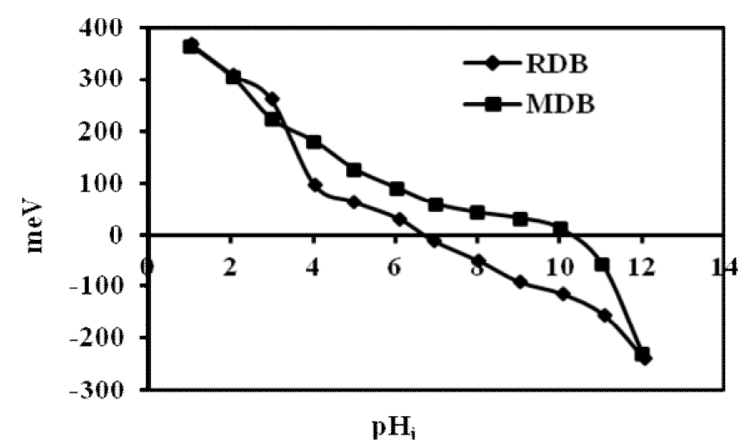

Figure 5. Zeta potential $\left(\mathrm{pH}_{\mathrm{pzc}}\right.$ curve of RDB and FDB

Studies on the adsorption of single metal ions $P b$ (II) and Zn (II)

In the present study, Langmuir adsorption isotherm was used to evaluate the maximum sorption capacity of the modified biosorbent, shown in Fig. 6(a) and 6(b) respectively.
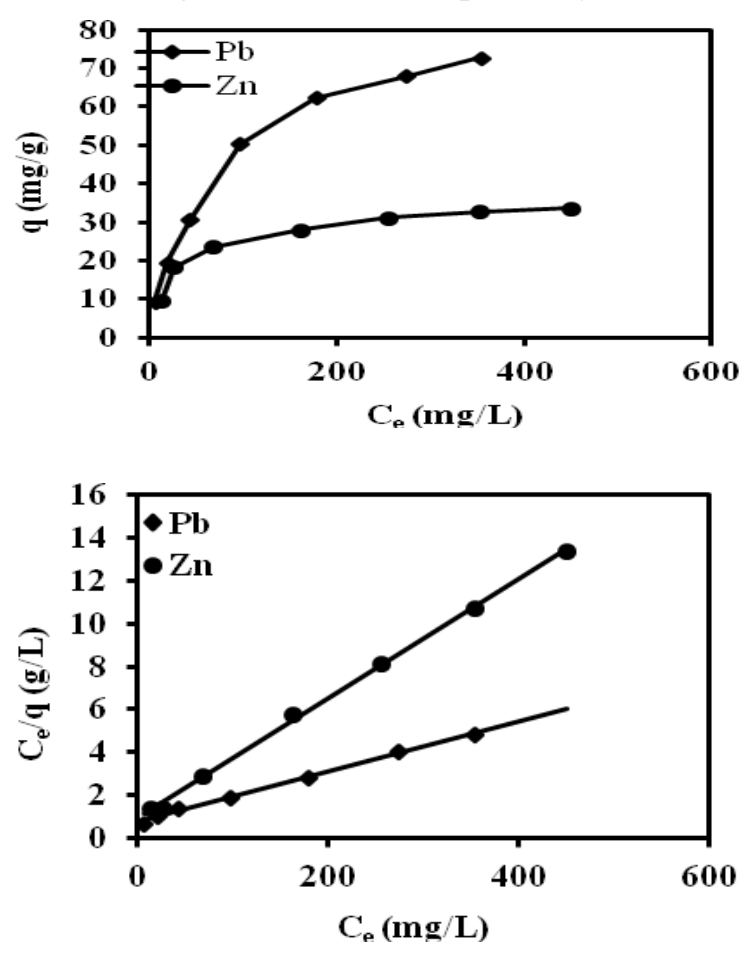

Figure 6. (a) Adsorption isotherm (b) Langmuir isotherm for $\mathrm{Pb}$ (II) and Zn (II) onto MDB

The equilibrium adsorption of metal ions on the biosorbent could be best described with Langmuir isotherms; sorption isotherms were evaluated using the popular linearized Langmuir model, represented by the following equation (3).

$$
\frac{\mathrm{C}_{\mathrm{e}}}{\mathrm{q}_{\mathrm{e}}}=\frac{\mathrm{C}_{\mathrm{e}}}{\mathrm{q}_{\mathrm{m}}}+\frac{1}{\mathrm{q}_{\mathrm{m}} \mathrm{b}}
$$

Where, $\mathrm{q}_{\mathrm{e}}=$ amount of adsorbed metal ions per gram of adsorbent, $(\mathrm{mg} / \mathrm{g})$.

$\mathrm{C}_{\mathrm{e}}=$ residual concentration of metal ions after adsorption, (mg/L).

$\mathrm{q}_{\mathrm{m}}=$ maximum adsorption capacity, $(\mathrm{mg} / \mathrm{g})$.

$b=$ binding constant, $(\mathrm{L} / \mathrm{mg})$.

The maximum sorption capacity was found to be $50.40 \mathrm{mg} / \mathrm{g}$ and $28.00 \mathrm{mg} / \mathrm{g}$ at 200 $\mathrm{mg} / \mathrm{L}$ for $\mathrm{Pb}$ (II) and $\mathrm{Zn}$ (II), respectively. In both cases, correlation coefficient $\left(R^{2}\right)$ value was found to be 0.99 , indicating that the Langmuir isotherm model fitted well, as shown in Figures 6(a) and 6(b), respectively. The above results are in close agreement with each other, suggesting thereby that heavy metal ions can be quantitatively sequestered on MDB. The sorption capacity of biosorbent is found to increase up to $400 \mathrm{mg} / \mathrm{L}$ initially, and remains almost constant, forming a plateau.

In the beginning the active sites on the biosorbent are easily available for metal ions; as the concentration increases the active sites on the biosorbent are almost all occupied by metal ions, hence the sorption activity on biosorbent becomes limited.

\section{Studies on the adsorption of binary metal ions $P b$ (II) and Zn (II)}

To understand the nature of interference of metal ions in aqueous solution, two typical heavy metals, $\mathrm{Pb}$ (II) and $\mathrm{Zn}$ (II) were considered at the concentration range from 25, 50, 100, 150 and 200 $\mathrm{mg} / \mathrm{L}$, respectively, as shown in Fig. 7(a) and 7(b).

Experiments were carried out batchwise. It became evident from the experimental results that metal ions adsorbed from the binary mixture are almost in agreement with the sum of the individual sorption capacities of respective metal ions. In the binary mixture, adsorption of $\mathrm{Pb}$ (II) was higher than $\mathrm{Zn}$ (II). This high sorption capacity of $\mathrm{Pb}$ (II) could be due to higher electro-negativity and 
smaller hydrated ionic size as compared to that of $\mathrm{Zn}$ (II), which creates greater affinity on the surface of biosorbent.

However, maximum adsorption of $\mathrm{Pb}$ (II) reduces from $50.40 \mathrm{mg} / \mathrm{g}$ in sole solution to 32.00 $\mathrm{mg} / \mathrm{g}$ in a binary mixture. Similarly, maximum adsorption capacity of $\mathrm{Zn}$ (II) reduces from 28.00 $\mathrm{mg} / \mathrm{g}$ in sole solution to $13.91 \mathrm{mg} / \mathrm{g}$ in the binary mixture. The reduction in adsorption capacity is due to the interference of one metal ion with another, thererby decreasing sorption capacities of both [23].

This occurs simply due to the fact that there is competition between the two metal ions for the fixed number of available functional sites occupied by the both metal ions in equilibrium [24]. Thus, available functional sites are primarily important for sequestering heavy metal ions from aqueous solutions.
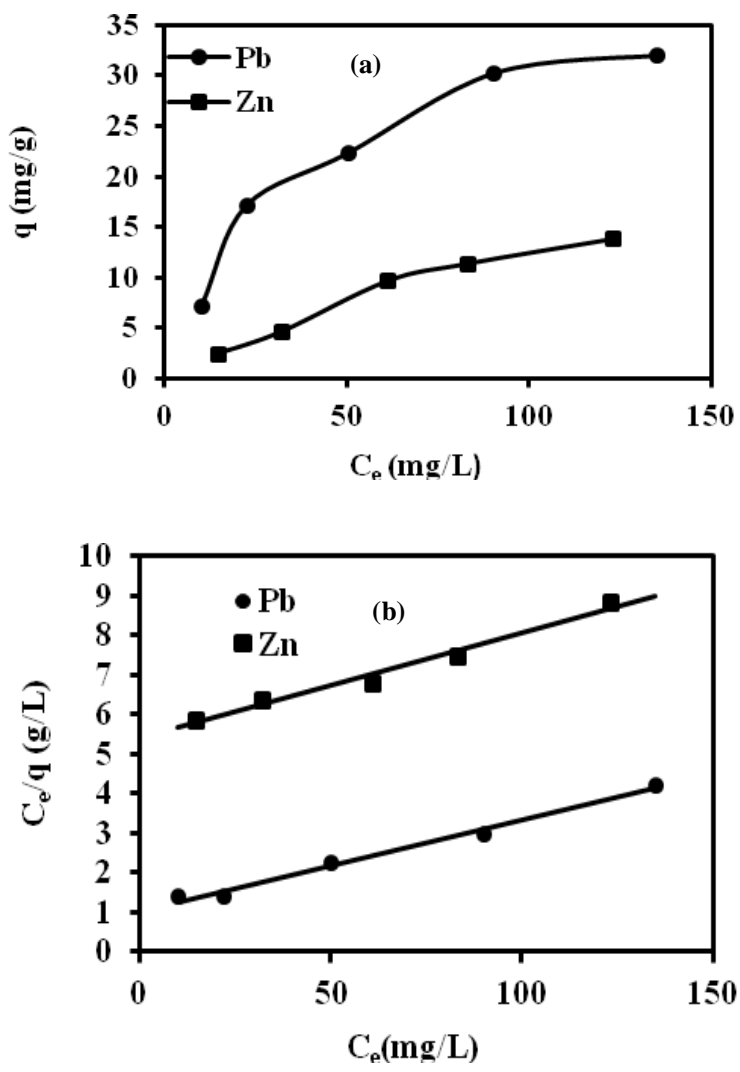

Figure 7. (a) Adsorption isotherm (b) Langmuir isotherm of binary mixture onto MDB

\section{Conclusion}

Individual studies on adsorption of two different types of heavy metal ions through modified biosorbents showed regular pattern of sorption capacity. The sorption of a binary mixture containing $\mathrm{Pb}$ (II) and $\mathrm{Zn}$ (II), showed reduction in the adsorption capacity of both the metal ions in a solution. The reduction could be due to the interference of one metal ion with another, present in the binary mixture, since the available active sites on the biosorbent are fixed and there is always competition between different metal ions for active sites.

The result shows that the amount of $\mathrm{Pb}$ (II) adsorbed was higher compared to $\mathrm{Zn}$ (II). Although there is interference of metal ions in the binary mixture, reducing the adsorption capacities of both metal ions, the study suggests that the modified biosorbent is capable of not only removing one type of metal ions, but also capable of removing mixtures of complex heavy metal ions present in industrial effluents quite effectively.

\section{Acknowledgments}

The authors would like to acknowledge Central Department of Chemistry, Tribhuvan University Nepal, for providing their laboratory for this research work. The authors are grateful to Department of Agriculture and Biotechnology, Padua University, Italy for chemical analysis.

\section{References}

1. M. Thirumavalavan, Y. L. Lai, L. C. Lin and J. F. Lee, J. Chem. Eng. Data, 55 (2010) 1186. https://dx.doi.org 10.1021/je900585t

2. P. L. Homagai, K. N. Ghimire and K. Inoue, Sep. Sci. Technol., 46 (2011) 330. http://dx.doi.org/10.1080/01496395.2010.50 6903

3. S. E. Bailey, T. J. Olin, R. M. Bricka and D. D. Adrian, Water Res., 33 (1999) 2469. https://doi.org/10.1016/S0043$\underline{1354(98) 00475-8}$

4. J. Anandkumar and B. Mandal, J. Hazard, Mater., 162 (2009) 276. 
5. D. C. Seo., K. Yu and R. D. DeLaune, Chemosp., 73 (2008) 1757. https://doi.org/10.1016/j.chemosphere.20 $\underline{08.09 .003}$

6. B. Xiao and K. M. Thomas, Langmuir, 20 (2004) 4566. https://dx.doi.org/ 10.1021/la049712j

7. A. Saeed, M. Iqbal and M. W. Akhtar, $J$. Hazard Mater, 117 (2005) 65.

http://dx.doi.org/

10.1016/j.jhazmat.2004.09.008

8. L. Li, F. Liu, X. Jing, P. Ling and A. Li., Water Res., 45 (2011) 1177.

http://dx.doi.org/10.1016/j.watres.2010.11.0 $\underline{09}$

9. D. Sud, G. Mahajan and M. P. Kaur, Biores. Technol., 99 (2008) 6017.

http://dx.doi.org/10.1016/i.biortech.2007.11. $\underline{064}$

10. G. Crini, Prog. Polym. Sci., 30 (2005) 38. http://dx.doi.org/10.1016/j.progpolymsci.200 4.11 .002

11. Y. F. Jia, B. Xiao and K. M. Thomas, Langmuir, 18 (2002) 470. http://dx.doi.org/10.1021/la011161z

12. L. Jin and R. Bai, Langumir, 18 (2002) 9765. http://dx.doi.org/10.1021/la0259171

13. K. N. Ghimire, K. Inoue, K. Ohto and T. Hayashida, Sep. Sci. Technol., 42 (2007) 2003.

http://dx.doi.org/10.1080/153638307013134 $\underline{61}$

14. K. N. Ghimire, K. Inou, K. Ohto and T. Hayashida, Biores. Technol., 99 (2008) 32.

http://dx.doi.org/:

10.1016/j.biortech.2006.11.057

15. J. Kour, A. Masi, M. Cagnin, P. L. Homagai, M. R. Pokharel and K. N. Ghimire, $J$. Nepal Chem. Soc., 30 (2012) 37. http://dx.doi.org/10.3126/jncs.v30i0.93 $\underline{33}$
16. J. Kour, P. L. Homagai, M. Cagnin, A. Masi, M. R. Pokhrel and K. N. Ghimire, J. Chem., 2013 (2013) 1. http://dx.doi.org/10.1155/2013/649142

17. E. L. Cochrane, S. Lu., S. W. Gibb and I. Villaescusa, J. Hazard. Mater, 137 (2006) 198.

http://dx.doi.org/10.1016/j.jhazmat.2006.01. $\underline{054}$

18. H. P. Boehm, Advances in Catalysis, Vol. 16, Ed. D. D. Eley, H. Pines and P. B. Weisz, Academic Press, New York (1966). https://doi.org/10.1016/S03600564(08)60354-5

19. R. M. Silverstein, G. C. Bassler and T. C. Morril, Spectrometric Identification of Organic Compounds, $4^{\text {th }}$ edition, John Willy and Sons, New York (1981). https://doi.org/10.1002/mrc. 1260300417

20. R. L. Shriner, C. K. F. Hermann, T. C. Morrill, D. Y Curti and R. C. Fuson, The Systematic Identification of Organic Compounds, $7^{\text {th }}$ Ed. Wiley, New York, (1998).

ISBN13: 9780471215035

21. K. Kurita, T. Sannan and Y. Iwakura, $J$. Appl. Polym. Sci., 23 (1979) 511. http://dx.doi.org/10.1002/app.1979.0702302 $\underline{21}$

22. S. Deng, Renbi and J. P. Chen, Languir, 19 (2003) 5058. http://dx.doi.org/10.1021/la034061x

23. Y. Li, H. Ma,B. Ren and T. Li, J. Anal. Meth. Chem., 2013 (2013) 8. http://dx.doi.org/10.1155/2013/649503

24. R. O. Adeeyo and O. S. Bello, Pak. J. Anal. Environ. Chem., 15 (2014) 1. http://www.pjaec.pk/index.php/pjaec/article/ view/187/170 